\title{
PROCESSES OF REFORMING THE EDUCATIONAL POLICY OF UKRAINE AND THE COUNTRIES OF THE EUROPEAN UNION: A COMPARATIVE ANALYSIS
}

\author{
Victor Bondarenko ${ }^{I}$ \\ Alla Semenova $\bowtie$ \\ Educational and Scientific center "Pedagogical skills of a high school teacher" \\ State University of Intelligent Technologies and Communications \\ 1 Kuznechna str., Odessa, Ukraine, 65029 \\ semenova.alla.vasilivna@gmail.com
}

Tamara Vysotska

${ }^{I}$ Department Theology and Religious Studies

National Pedagogical Dragomanov University

9 Pirogova str., Kyiv, Ukraine, 01601

$\triangle$ Corresponding author

\begin{abstract}
A comparative comprehensive analysis of the socio-pedagogical problem field of modernization of the educational system of Ukraine and the EU in the context of administrative reform and taking into account economic needs and the establishment of universal democratic values has been conducted.

A comparative pedagogical study of the theoretical, organizational, methodological and regulatory principles of reforming the educational system of Ukraine, which is currently acquiring national features and integrated into the world educational space, has been carried out

Conceptual principles of reforming the educational system of Ukraine as a basis for improving the quality of life of citizens from the standpoint of an innovative educational project in the context and professional psychological and pedagogical aspects of training in the field of educational policy have been theoretically substantiated. The provision is that education, like other institutions of public life, requires operational and strategic management actions, aimed at its modernization and renewal.

A conceptual integral dynamic model of reforming educational policy in Ukraine with substantiation of methodological approaches and theoretical positions has been developed on the basis of comparative pedagogical research.

A necessity of expansion and qualitative improvement of the network of preschool educational institutions has been proved.

There are trends that Ukrainian secondary education will eventually become on a par with the world standards of secondary school.

A need to create and coordinate a strong system of out-of-school education in Ukraine has been justified, as the mass unemployment of children and youth in out-of-school time entails huge negative consequences.

Peculiarities of reforming the system of training of working professions and vocational education in Ukraine have been specified.

A strategic issue is the state policy on teacher training.

Ukrainian origins of the phenomenon of pedagogical skill as a fundamental basis of the theory and practice of educational policy to improve the quality of teaching and learning in EU countries have been revealed.

A necessity of development of a target program of professional and pedagogical selection and preparation of experts in the field of educational policy for Ukraine and an algorithm of estimation of its efficiency on the basis of the comparative analysis has been proved.

The content of the concept of "educational policy" has been clarified, knowledge of the regulatory framework for reforming educational policy in the EU has been deepened.
\end{abstract}

Keywords: educational policy reform, pedagogical skills, quality of education, EU educational policy.

DOI: 10.21303/2504-5571.2021.002195

\section{Introduction}

The practical experience and theoretical generalizations, accumulated in Ukraine and in the European Union countries on the nature, algorithm and impact of globalization transformations 
become especially relevant in the context of Ukraine's educational policy before its synchronization with the standards of leading foreign countries. The signing of the Association Agreement between Ukraine and the European Union in 2014 finally consolidated the European vector of development of the Ukrainian state in all areas, including education [1]. Rapid global changes in the life of modern society, the challenges of the global pandemic, global scientific and technological development, demographic changes, etc. make new demands on the system of school, vocational and higher education, the organization of continuous adult education. All this necessitates the definition of new relevant content, main directions, mechanisms for forecasting, development and implementation of state educational policy in Ukraine, which would meet both the needs of present and future sustainable development of the state. After all, education is a strategic resource of socio-economic and scientific and technological development of society, improving the welfare of people, national security and interests, strengthening the authority and competitiveness of the state in the international arena [2].

Education policy is interpreted as "the sphere of relationships between individuals, different social groups in order to use government institutions to realize their interests and needs" [3]. State educational policy is an officially defined, organized and purposeful activity of the state and its subordinate institutions, aimed at the functioning and further development of the education system as a leading institution of a democratic society [4]. The European Union's education policy is based on the fact that each EU country is independently responsible for its own education system. EU policy in this area is designed to support action at the national level and to help solve common problems [5]. November 19, 2020 Ministers responsible for higher education in Europe, meeting online in Rome, noting that 21 years have passed since the signing of the Bologna Declaration, reaffirming the commitment to develop a more inclusive, innovative, interconnected and sustainable European Higher Education Area (EHEA), specified "Recommendations to national authorities to improve teaching and learning in higher education in the EHEA" in the text of the "Rome Ministerial Communiqué" [6].

It is logical, that the use of new technologies requires professional qualifications, social competence, civic responsibility from educators-managers at all levels. In addition, such specialists should be characterized by developed analytical and prognostic thinking, have the skills of reflection, and, above all, be characterized by appropriate personal moral qualities, be patriots of their country [7]. Therefore, the above-mentioned modern features of the processes of reforming the educational policy of Ukraine and the European Union require in-depth comparative analysis in order to specify the uniqueness of a holistic dynamic model of reforming educational policy in Ukraine based on creative application of the experience of the European Union.

\section{1. Chronological boundaries of the study}

Chronological boundaries cover the last decade of the XX - beginning of the XXI century. The lower chronological limit is determined by the Act of Independence of Ukraine - a document, adopted by an extraordinary session of the Verkhovna Rada of the USSR on August 24, 1991, which proclaimed the independence of Ukraine and the creation of an independent state - Ukraine. This provided an opportunity to identify the most important parameters of reforming the education system in Ukraine, the essential characteristics, direction and progress of reforms. 2021 determines the upper chronological limit of the study, which updates changes in educational policy in Ukraine by adopting Professional Standard for the group of professions "Teachers of Higher Education" by the Ministry of Economy, Trade and Agriculture of Ukraine by March 23, 2021 Order No. 610.

In order to extrapolate the experience of the European Union to Ukraine, it was important to study the realities of EU education systems, which led to a study of the processes that began on July 1, 1987, with the entry into force of the Single European Act, signed in February 1986. This document defined the further goals of European integration. In particular, it set the goal of creating a single internal market by January 1, 1993 (the next stage of economic integration, which provided for the harmonization of economic policy and institutions), introduced a common policy in the social sphere, in the field of scientific and technological development, environmental protection. This document also amended the Treaties, establishing the European Communities, in particular the creation of the European Council, and extended the integration process to foreign policy. In addition, the Single European Act raised the question of the creation of the European Union, which 
was to become an institution not only economic but also political. The first agreement, regulating relations between Ukraine and the European Union, was the Partnership and Cooperation Agreement, signed on June 16, 1994.

\section{2. Territorial boundaries of the study}

Territorial borders cover Ukraine as a key unit of research. At the same time, within the framework of comparison, the European Union, the economic and political union of independent countries, located in Europe, was chosen as another unit of the research. The member states of the European Union are the countries that have joined the European Economic Community since 1958. The European Union was originally founded by six countries, but since 1958 there have been five stages of successive EU enlargement. On 1 May 2004, 10 new members joined the EU, the greatest enlargement in the Union's history. Following the UK's exit in 2020, the EU has 27 member states. The list of European Union member states (as of February 1, 2020): Austria, Belgium, Bulgaria, Greece, Denmark, Estonia, Ireland, Spain, Italy, Cyprus, Latvia, Lithuania, Luxembourg, Malta, the Netherlands, Germany, Poland, Portugal, Romania, Slovakia, Slovenia, Hungary, Finland, France, Croatia, Czech Republic, Sweden.

\section{3. Analysis of literature sources}

Examining the processes of reforming the education system in Ukraine from the first days of the Ukrainian state, it should be noted, that due to the activities of the Ministry of Education and Science and education authorities in the regions that began to reform the industry, education began to move to national values world scientific and educational space. In 2005, Ukraine became a participant in the Bologna Process, joined other initiatives of the European Union, aimed at deepening the international mobility of students and teachers, resumed the education of foreigners in Ukrainian HEIs, and so on. In Ukraine, scientists in the field of education have studied the following issues:

- pedagogical principles of school education reform in the first years of Ukraine's inded pendence in the conditions of state formation, which were declared in the State National Program «Education» («Ukraine of the XXI century», 1993) [8];

- public administration aspect of education reform in Ukraine from the standpoint of the competency-based approach to the training of educational leaders [9];

- professional training of teachers in the developed countries of the world with the defif nition of its features in key aspects: legislative support; structure, content, forms, methods and technologies of professional training of pedagogical workers [10];

- transformations in education in the aspects of decentralization-centralization, humanizaz tion processes, standardization and differentiation of education in the EU and the USA; approaches of foreign countries, used to implement reforms; prospects for the use of foreign experience in Ukraine [1].

In foreign research, the study of the experience of European countries distinguishes three types of education management: centralized, decentralized and decentralized with enhanced school autonomy [11]. The centralized type means that the implementation of educational tasks is provided by the state, and decisions on curricula, teaching methods, employment, wages, etc. are made at the central level [12]. This type is typical for Austria, Greece, Spain, Italy, Portugal, France. The decentralized type is defined by the delegation of powers to local governments (communities) to implement most of the educational tasks [13]. The transfer of educational tasks to local self-government is based on the belief (doctrine) that members of such local communities - taxpayers, parents, teachers, educators - better understand the educational needs of children in local communities and schools. Therefore, their motivation to take care of the better functioning of the educational institution in their area is much higher [14]. The decentralized type with enhanced autonomy of an educational institution is characterized by the provision of most of the powers directly to educational institutions, in particular regarding the organization of the educational process, personnel issues, use of resources [15, pp. 108-117]. On this basis, the three main systems of financing the education system, which provides different ways of transferring funds from the central level, are determined: directly to educational institutions, to local governments on the basis of agreements, to local governments on the basis of agreements with further distribution between educational institutions by established rules [16]. Lithuanian researchers [17, pp. 659-671] note that increased competition 
between localities can lead to greater efficiency in education. The Hungarian researcher [18] points out that centralized management systems in general, and management in education in particular, cannot contain key stakeholder groups in the decision-making process (weak democratic political legitimacy).

This reduces the ability of stakeholders to implement solutions (low professional legitimacy). He notes that these shortcomings can lead to a "crisis of legitimacy" in centralized systems.

Foreign scholars, advocates of decentralized education systems, place greater emphasis on the fact that such educational policies improve the quality of education and meet local demand through better awareness of local needs, provide more democratic control and regulation [19]. Among the challenges that states may face in the process of reforming the education systems of the EU, European researchers include problems of efficiency, fairness and responsibility, for which poorly coordinated provision leads to fragmentation of the system. After all, according to the German researcher, some of these problems arise due to the fact that the central ministries do not perform the functions of monitoring and training to actually make decisions and manage the government at lower levels. They may also arise from difficulties in the implementation of management decisions at the local level due to insufficient funding from individuals or entities that perform only decision-making functions. M. Bernbaum [20, p. 211] also emphasizes the need to clarify the roles and responsibilities of the persons concerned when working with ministries of education and the need to support capacity-building to help executors of orders effectively perform their duties.

National authorities in EU countries are increasingly demonstrating new ways to reform education policy [21]. Thus, the Swedish researcher [22, pp. 266-282] emphasizes the importance of control over educational outcomes, requirements for quality control, standardized testing, evaluation and implementation of national criteria. In addition, national authorities may introduce "soft" forms of control [23]. This can be: dissemination of information, joint analysis and strengthening the use of assessments and quality control [24]. This trend can affect many aspects of educational practice [25]. In different periods of modern Ukrainian history, the process of reforming education was with varying intensity and to a greater extent concerned a particular segment of education [26]. Therefore, there is an urgent need to analyze each of them in particular and as a whole, starting with preschool education in order to professionally reflect on the processes of educational reforms in Ukraine: their causes, achievements and forecasting and prevention of problematic aspects in the future.

\section{4. Concretization of the revealed contradictions, statement of the problem}

The comparative analysis of the processes of reforming the educational policy of Ukraine and the European Union within the chronological framework of the study, generalization of scientific sources, current challenges to the quality of education and the European vector of development of the Ukrainian state in all areas, including education, practical experience, allowed to reveal contradictions, formed, in particular, between:

- significant achievements of scientists of Ukraine and EU countries in the field of building an effective and innovative education system and insufficient research of the progressive experience of these countries in order to implement it in Ukraine;

- the need to take into account trends in the development of education systems in the EU and the lack of comprehensive study and forecasting of innovative areas for updating the content of education in Ukraine;

- Ukraine's desire to integrate into the European educational space and the weak readiness of Ukrainian educational institutions to adhere to the basic principles of good quality assurance of education;

- anticipation and dynamism of the processes, taking place in the national education systems of European countries, and conservatism in the management of complex reforms in the education system of Ukraine;

- social demand of the state for teachers of new formation and outdated views on the role and functions of teachers in the system of their professional training;

- the urgent need to reform educational policy in Ukraine and the lack of professionally trained educators and highly professional, honest, self-developed educational experts who would be willing to successfully solve complex problems at the state level; 
- the obvious need, due to the lack of a procedure for professional selection and qualification assessment of experts in the field of education, support for strategic development and innovative potential of teaching and learning at both national and institutional levels, through empirical research in education, projects and pilot projects, as well as the collection and use of data on education, while ensuring the confidentiality of data;

- the need to develop domestic cultural and educational programs that meet national traditions and do not contradict global and European trends and the lack of systematic research data on the selection and training of specialists in the field of educational policy and educational experts to reform educational policy.

These contradictions in the theory and practice of improving the education system of Ukraine have identified the problem of research, which is to find ways to develop and implement a holistic dynamic model of reforming education policy in Ukraine based on the progressive experience of EU countries on European integration, globalization and democratization. Solving the outlined problem will allow:

- Implementing the European integration progress of education reform in Ukraine, to preserve the state identity and awareness of professional and pedagogical national-Ukrainian identity of a teacher in modern conditions, as a source of formation and development of professional culture of teachers, the core of which is humanistic orientation, spirituality and professionalism under condition of functioning on the basis of the national-cultural, value-worldview and value-knowledge paradigm;

- to determine the theoretical and methodological concepts of a holistic dynamic model of reforming the educational policy of Ukraine on the basis of comparative studies to ensure the success of improving the education system of Ukraine;

- to outline the prospects for the preconditions of cultivation of ideas of personal orientation in the education system; regulations for creating projects to nationalize education; organizational means and forms of competition for projects to update the content and technology of education; algorithm of actions in the direction of establishment of democratic style of management in educational institutions; model of the project of a new resource educational policy as a whole.

The introduction of the ideas of comparative studies, humanistic pedagogy, as well as the development of methodological foundations for reforming educational policy on the basis of the general scientific holistic synergetic approach is an objective need of the modern domestic education system. The relevance and necessity of in-depth scientific development of these important ideas of the policy of reforming education systems, as well as the identified contradictions and insufficient level of theoretical and methodological understanding and practical development of this problem led to the choice of the article topic.

The purpose of the study is to determine the features of the processes of reforming the educational policy of Ukraine and the European Union in order to specify the uniqueness of a holistic dynamic model of reforming educational policy in Ukraine based on the creative application of the experience of the European Union.

\section{Materials and methods}

The methodological basis of the study is determined by:

- provisions on the general connection, interdependence and integrity of the phenomena and processes of development of society, the holistic approach to the social essence of an individual as a subject of development;

- philosophical ideas of the unity of the world and the unity of scientific knowledge;

- social and psychological-pedagogical works, which present: interpretation of the synergetic approach, based on the ideas of nonlinearity, integrity of perception of the world;

- the concept of self-actualization, self-development and self-realization of an individual in the process of professional activity;

- principles of interrelation of theory and practice.

The theoretical basis of the study was multidisciplinary multifaceted characteristics, analysis and evaluation of basic concepts of educational policy, ideas, positions and conclusions in the scientific literature in the following areas: 
- methodological approaches of comparative pedagogy to the study of educational phenomena abroad in relation to social and cultural contexts, in the dimension of national and world transformations;

- patterns of formation and development of personality;

- activity of a subject;

- personal and activity approaches in their organic integrity;

- design of educational systems and pedagogical design; synergetics and general systems theory.

The research was based on the philosophical provisions of the theory of scientific cognition as a social, multidimensional, dynamic phenomenon, defined by a unified format in the form of an educational competence standard; scientific works of researchers and practitioners on innovative transformations in the education system.

\section{2. Research methods}

The study used a comparative logical-historical analysis and synthesis of philosophical, psychological and pedagogical works, official and regulatory documents, curricula, textbooks and manuals; analysis of works in the field of theory of scientific revolutions, concepts of education, philosophy, psychology and pedagogy on the researched problem; study, analysis and generalization of the experience of reforming education systems in Ukraine and EU countries.

\section{Results}

The leading idea of the research concept is the provision that Ukrainian society needs a holistic strategically balanced educational policy and, accordingly, patriots-professional educators-managers of all levels for its development and implementation, which should be characterized by appropriate professional and pedagogical and personal moral and managerial qualities, because the role of teachers in the education system is crucial. In this context, special importance arises in the issues of concretization of axiological and nation-building content and development of methodology for training competent specialists in the field of educational policy for Ukraine on the one hand, and personal and professional selection, training for work in the field of state education policy - on the other. Because the degree of desire of graduates of general secondary, vocational and higher school of dynamic civilizational changes, their spiritual, moral and patriotic upbringing, ability to productive service to the Motherland, creativity and self-realization in the society of the XXI century depends on the implementation of wise scientifically and politically balanced educational policy.

The concept of the study contains three interrelated concepts that contribute to the implementation of the leading idea: methodological, theoretical and organizational-methodological.

The methodological concept combines fundamental philosophical ideas, first of all, the provisions of philosophical anthropology, existentialism, personalism, as well as the relationship and interaction of different approaches to general and specific scientific methodology to study the reform of educational policy of Ukraine and the European Union:

- comparative approach, which, based on the analysis of commonalities and differences in the experience of reforming the educational policy of Ukraine and the EU countries, provides the generation of positive experience in order to extrapolate it in Ukraine;

- Human-centered approach, in which a person is seen as a unique integrity, which has inexhaustible opportunities for personal development, suggests that promoting self-realization of learners can directly help solve the problem of improving the quality of life of the population;

- synergetic approach provides a basis for considering a holistic dynamic model of educational policy reform as a complex system that is out of balance and has great potential for improvement through open interaction with the environment and for which there are several alternative ways of development; study of personality as an open, purposeful system; provides consideration of professional training of educators-managers, experts in the field of education as a holistic socio-pedagogical dynamic system;

- axiological approach determines the focus on universal, worldview values; determines the focus on the harmonious development of an individual as the highest value of society;

- acmeological approach orients the training of teachers, educators, managers, experts in the field of education on the formation of their own acmeological position, which involves their 
focus on personal acme-oriented self-development and acmeological support of the movement of those learning to new stages of development;

- andragogic approach explains the idea of non-interference, but the stimulation of internal forces (motivation) of an adult to self-study, to increase his/her educational needs.

The theoretical concept defines a system of ideas, concepts, source categories, basic concepts, definitions, without which it is impossible to understand the essence of the problem:

- provisions of the philosophy of education, pedagogical and age psychology, pedagogy, modern theories of cognition and personality development;

- conceptual provisions on openness, understanding of the single educational space as a resource of socio-economic and socio-cultural development;

- prognostic approach, substantiating world, European, national and regional projects of education modernization;

- philosophical and pedagogical principles of analysis of problems of international education and comparative pedagogy;

- scientific works on modern approaches to the philosophy of education;

- theoretical and methodological principles of professional pedagogical education in Ukraine;

- scientific bases of pedagogical innovation, comparative studies and higher school pedagogy.

The theoretical concept contains the following basic provisions:

- the process of reforming educational policy should ensure not only the achievement of the goals of the education system, but also the realization of personal meanings of its subjects, their self-realization in society, improving the quality of life of the population;

- the orientation of the principles of reforming educational policy on an individual involves the transition from the philosophy of authoritarian "influence" to the philosophy of democratic virtuous "interaction";

- the teacher's personality is seen as a special form of his/her involvement in life, the inner world of his/her students, which is significant for their existence and development of the transformation of the hierarchy of values, attitudes to themselves and the world, further self-development and self-realization.

The organizational and methodological concept provides for the development of scientifically sound organizational and pedagogical support of creative use of constructive ideas of the relevant experience of the European Union in Ukraine, on purposeful optimally organized interaction of subjects in the education system in Ukraine, characterized by a certain mechanism of educational policy reforming, consistent implementation of methods, techniques and allows you to get the planned result of sustainable development. The basis of the organizational and methodological concept is the strategy and target program of professional and pedagogical selection and training of specialists in the field of educational policy for Ukraine in terms of European integration, which is justified, bearing in mind certain professional requirements for Ukrainian teachers, taking into account European integration processes; study of modern trends and concepts of education development in the EU countries; identification of the features of the integration of education in Ukraine into the European educational space; identification of opportunities for the implementation of constructive ideas of foreign experience in educational institutions of our state.

The leading idea of the study, its concepts are embodied in the general hypothesis of the study, which is based on the assumption that the effectiveness of a scientifically sound and developed holistic dynamic model of reforming education policy in Ukraine in terms of European integration, which is based on updated goals and taking into account the peculiarities of state education systems in the European experience, allows to improve the quality of education in Ukraine, its competitiveness in the European labor market, at its comprehensive implementation through the imperative to recommendations for legislative, scientific-methodological and organizational-methodological pedagogical support of creative use of constructive ideas of the relevant experience of the EU countries in Ukraine, on the reflexive basis, taking into account the mental-national and economic-legal, state features.

From the very beginning of the history of independent Ukraine, there were good preconditions for reforming education in all its segments, starting with preschool education and ending 
with the training of highly qualified personnel. Ukraine had a strong network of educational institutions, a mobile and efficient model of education management, a good material and technical base, and so on. [27]. However, at the same time, economic decline, demographic problems and a certain disorganization of socio-economic development have affected the development and modernization of education. These problems immediately had a negative impact on the reform of education in Ukraine: the network of preschools was reduced, and some of them were transferred to the sphere of commerce; the process of urbanization and reduction of the number of rural schools has negatively affected the quality of education in rural areas; gradually, higher education began to be reformatted uncontrollably, especially in connection with the formation of a system of private higher education institutions, which favored the development of a certain segment of educational services with a tendency to train lawyers, economists and other professions that have become fashionable and in demand; leadership positions were lost in a number of other fields of knowledge, especially fundamental, engineering and others, as well as those that began to lose their relevance due to the decline of rocketry, aviation and shipbuilding, as well as teacher training. Accordingly, this affected the lag behind the needs of the content of education and its optimization. Educational principles in the work of educational institutions were slowly collapsing, and out-of-school education, which was previously based on non-economic support of the state and economic entities in the upbringing of children and youth, was declining. All this could be maintained only with a clear and purposeful policy of the state in the field of education and involvement of business in the process of reforming the industry. However, this did not happen and education began to reform itself without sufficient support and correction from the state and society.

The processes that have taken place and are taking place in this area show that despite all efforts in Ukraine: "In rural areas, only $40 \%$ of children aged one to six attend preschool, compared to $64 \%$ in cities. In addition, although the existing pre-school institutions offer a total of 1.1 million places for children aged one to six, they have 1.29 million children. The above demonstrates one of the main problems of the preschool education system - insufficient number of places and overload. This problem is especially acute in large cities, where an average of 117 children applies for every 100 places" [28]. Eventually, the issue was exacerbated, primarily due to the mass closure of rural kindergartens and the sale of kindergarten facilities in cities during the demographic crisis of the 1990s. Due to the decline of the village, most rural communities have become unable to maintain children's educational institutions and have shifted the care of raising and educating preschool children to their parents. It is this circumstance that has slowly become a significant obstacle to the social self-realization of young parents, especially young mothers, who have been forced to raise their own children instead of working. Thus, if in 1990 there were 24.5 preschools in Ukraine, then, say, in 2004 there were only 14.9 thousand. And although later this trend began to change for the better, the number of children's educational institutions in Ukraine today is clearly insufficient.

Since 2015, the financing of state preschools has become the responsibility of local authorities, which has emerged as part of the overall decentralization in Ukraine. Due to the rather strict legal restrictions that still exist in Ukraine, the system of private preschool educational institutions is still poorly developed, the number of which still reaches only a few hundred units. The holistic system of child education in Ukraine continues to be insufficiently provided by the state. More than 300,000 people work in more than 15,000 kindergartens, including 173,000 technical staff and 134,000 pedagogical staff, $68 \%$ of which are educators. These are mainly people of active age categories, of which $33 \%$ are younger than 35 years, $61 \%$ - aged 35 to 60 years, and only $6 \%$ older than 61 years. At the same time, there is a constant shortage of staff in the system of preschool education, especially in the positions of primary level - assistant educators.

At the same time, Ukraine has a well-developed and high-quality network of training for preschool education staff. In particular, they are prepared by 93 higher education institutions of Ukraine, although not all graduates of these educational institutions go to the profession for one reason or another. The main factor, preventing this, is the low salary in preschool institutions, which is slightly more than the small salary of a Ukrainian teacher. The network of preschool educational institutions of Ukraine itself needs to be expanded and qualitatively improved. As for the countryside, the issue can be solved here by diversifying the forms of organization of preschool education, with the involvement of teachers, 
who are released as a result of the reduction of the school network in the countryside. Kindergartens should be built in cities, at the expense of all possible resources, until their needs are fully met. This is a joint task of the Ministry of Education and Science, the Ministry of Regional Development and other ministries and departments and local authorities involved. The Ministry of Education and Science should also consider legislative support for the development of the system of private kindergartens, which could significantly bring us closer to solving the existing problems in this area.

In addition, Ukraine should benefit more from the work of international partners, including the Early Childhood Workforce Initiative (ECWI), the Institute for Development Results (R4D), the International Step-by-Step Association (ISSA), the Bernard van Leecher Foundation, Open Society Foundations, ELMA Foundation, Institute for Educational Development (IED) and others.

Successes or failures in the system of preschool education are the basis, on which education "starts" at school. The level of socialization and intellectual development of children, laid down in preschool age, largely determines the success of the school, but this is only one of the factors of its successful or less successful activities. The processes that began in Ukrainian society in the 1990s had a significant impact on the education system. The deindustrialization and urbanization of Ukraine, which are directly related to Ukraine's entry into the globalized world, have become disastrous, especially for the rural school. It slowly began to become incomplete, and therefore inefficient. The city school, in turn, has undergone changes, related to the need for both organizational restructuring and transformation of the content of education, which also could not but affect the quality of its work.

Then, already in the 2000 years, an intensive process of reducing the network of rural schools and moving them to a lower organizational level began. As a result, the network of rural schools began to shrink at an unprecedented rate. Thus, every year in Ukraine the number of such closed rural schools began to reach 200-250 units, in addition, the teaching of basic subjects deteriorated, problems with transportation of pupils regarding the location of full schools worsened, teacher training deteriorated (due to falling prestige of the profession, etc.), there was a shortage of teachers of foreign languages, mathematics, physics, chemistry, etc. [29]. Due to various circumstances, these and other problems were solved inefficiently and with a significant delay. School education has significantly lost its effectiveness, and some schools have begun to openly degrade.

An objective assessment of the quality of school education according to the PISA system, which began in Ukraine in 2018, showed the following results: $36 \%$ of Ukrainian 15-year-old pupils do not reach the basic level of mathematics, $25.9 \%$ are not able to properly understand and use used written texts, $26.4 \%$ have no minimum natural science knowledge. The difference between the success of our pupils and ones from the countries of the Organization for Economic Cooperation and Development is equivalent to a lag of one year of study. According to this indicator, Ukraine was in the fourth place from the bottom in the list of 79 countries, in which the study of the quality of school education was conducted by the PISA system [29].

In the field of school education, the main achievements of previous periods of education reform in Ukraine, such as 12-year school education, twelve-point assessment of pupil achievement, the introduction of external evaluation, etc., are no longer in doubt, let alone audited. Since 2014, the reform of education in Ukraine has gone upwards, although not without certain errors and deviations, which is typical of the process of transformation in any other sphere of society. Reforms have been significantly hampered by the ongoing political struggle in Ukraine. However, it should be recognized, that this fact is common to all other countries that have undergone similar transformations.

Among all the significant changes in the field of school education that have taken place in Ukraine since 2002, the most noticeable and significant is undoubtedly the introduction of the reform of the "New Ukrainian School", which has been working in recent years. We did not set ourselves the task of scrutinizing the content of education that appears to us in this perspective, but only managed to assess its organizational and financial component. The New Ukrainian School was based on the Finnish model of education, which is highly valued in Europe and the world. And although its pilot development was clearly insufficient, as only 100 schools were involved in the pilot project for a relatively short time, it begun to operate and began to be well funded by the Government of Ukraine. UAH 1.2-1.4 billion is allocated annually from the state budget of Ukraine 
for the New Ukrainian School, which, of course, is a significant amount for Ukrainian education. These funds are used to buy desks and other furniture, color printers, multimedia boards, movie projectors and other gadgets for the country's schools. The change of government did not affect the amount of NUS funding, but by the logic of the process, it should have increased as the number of pupils and classes, working under this program, increased. However, so far this is not observed. Within the framework of the NUS concept, the training and retraining of teachers is well established, but in the curricula of teachers in pedagogical universities and colleges, this issue has not yet been widely covered. At the same time, the NAPS of Ukraine, scientists-educators of pedagogical universities and relevant institutes of the Ministry of Education and Science should pay close attention to the content of NUS education and teaching methods in them, as well as adapt the Finnish experience to Ukrainian realities.

The next problems in the development of the Ukrainian school are related to the adjustment of the school network and school funding, and, in particular, to the salaries of educators, which are designed to motivate teachers in the profession. The issue of correction of the school network is closely synthesized with the administrative reform, as the latter changes the status of settlements, forms the United Territorial Communities (UTC) with new centers, affects the construction of roads and so on.

Trends in the further development of Ukrainian schooling directly follow from the realities that have developed here today. There are currently about 15.5 thousand schools in Ukraine, more than $60 \%$ of which operate in rural areas and a significant part of them is declining. Today, 1.1 million pupils out of 3.6 million pupils study in rural schools, while 2.5 million study in urban schools. On average, the number of pupils in rural schools is correlated with urban schools as 1 to 4 , and this process is constantly accelerating. Therefore, it is clear, that one of the main tasks of organizational reform of secondary schools in Ukraine is the rapid and high-quality formation of support schools and transportation of rural children to these schools. The Ministry of Education and Science, local education authorities and UTCs should focus on this and not artificially restrain the closure of small schools in rural areas. This will only help to improve the level of education of rural children and make them competitive in the later stages of their lives and education, and support schools will be better provided and staffed with teachers. Because according to research [30], due to the shortage of some teaching professions, every tenth teacher in Ukraine now combines the teaching of several disciplines, and, for example, $15 \%$ of schools do not have mathematics teachers at all. At the same time, according to the European report "Monitor of Education and Learning" [31], the role of the teacher is much more important than other factors that affect the successful learning of pupils. In Ukraine, a rural school is openly inferior to an urban one in all respects. According to the source, cited above, $70 \%$ of all teachers with secondary education work in rural schools. In addition, the situation in the cities is much better with the technical equipment of schools and the provision of the educational process.

Ukrainian education in general and schools in particular are poorly funded. The Law of Ukraine "On Education" is known to define the lower limit of state funding for education $-7 \%$ of GDP. In Ukrainian conditions, the absolute figure of these expenditures does not look so convincing. Thus, in Ukraine, one pupil spends about 27 thousand dollars for the entire period of his/her education at school, while in accordance with world practice, this amount should reach 50 thousand dollars. The salaries of educators also remain too low. A novice teacher receives about 4 thousand UAH per month, and a teacher with experience more than 8 thousand UAH. This distracts young people from the teaching profession, teachers are aging, the profession is rapidly losing social prestige. This position is a clear threat of staff shortages for Ukrainian schools. However, the solution of these issues is fully within the power of school founders and they do not need regulation at the legislative level, especially in our difficult conditions of administrative-territorial reform in Ukraine.

Thus, it is easy to see that the Ukrainian school is being reformed and over time will become on a par with the world standards of high school. However, we note that in the process of this reform we see many shortcomings, the main ones being: low funding for education, lack of prognostic view on the content of education and its organization within the state or region, attempts to impose harmful decisions on Ukrainian schools.

The state and the government should take care of the revival of out-of-school education in Ukraine on a free basis with its consistent commercialization as our citizens become wealthier. 
This would have a huge positive effect with fateful social consequences. From our point of view, the Church should be involved in this work [32]. Today, there are about 38,000 religious communities in Ukraine, almost all of which, together with the school, could organize extracurricular activities with children. Religious organizations have every opportunity to do so, except for the impulse from the state and the government to start such joint work with the school. The state could easily send such a signal, for example, through the All-Ukrainian Council of Churches and Religious Organizations, the leadership of individual churches and religious organizations, Sunday schools, missions, fraternities and other organizational structures of religious organizations. Carrying out such work would not only make it possible to implement socially significant actions of ecological nature: cleaning of settlements, organization of collection and processing of recycled materials, cleaning of cemeteries, etc., but would also teach children to work, raise common goals over personal ones, would solidify Ukrainian society, make it stronger and more stress-resistant.

Next, we consider the features of reforming the system of training workers and the former secondary professional education, ie technical schools and colleges. Its main problems are the lack of understanding of what personnel the system should train, for whom to train them, at whose expense and on what material base to do that. According to various data, there are currently 600 to 800 vocational schools in Ukraine of various forms, orientations and subordination. Vocational education is probably the most problematic segment of Ukraine's educational environment. Therefore, the state (represented by the Ministry of Education and Science), local authorities and leaders of the industrial sector should be more active in making promising decisions to save the vocational education system in Ukraine. Such decisions should be based on the following principles: understanding the needs of the economic system of the country in personnel, mandatory implementation of the principles of dual education, business involvement in the training of workers for own production, state participation in training professionals to serve housing, transport and other critical infrastructure of the country.

Naturally, the state can and should maintain that part of vocational institutions that train in-demand professions without care for their future employment, but these educational institutions cannot dominate the vocational training system. Their lion's share should become an integral part of the relevant ministries and departments, large corporations, and so on. Therefore, it is urgent to determine the real subordination of vocational education institutions, linking them with the stakeholders and their work. The state should keep under its care and financial support only the general education component of training specialists, i. e. obtaining complete general secondary education, along with a relevant specialty, by them. Businesses, which are in dire need of professional staff, have already been involved in their training, and if the legislation is adjusted accordingly, business structures will begin to show total interest in this issue. They will also ensure the implementation of the principles of dual education, minimizing the need for vocational education to maintain the once huge training and demonstration base. The state, represented by educational bodies, should only develop algorithms for cooperation between a student of a vocational education institution, the institution itself and an employer.

In the future, the state and its bodies will be trained to ensure the functioning of critical infrastructure, but these subsystems will have to be distributed among the relevant ministries, departments and local authorities. The Ministry of Education and Science and its local bodies should retain the functions of methodological management of professional educational institutions, some management and arbitration functions, control over the quality of education and spending of budget funds. As for the former technical schools and colleges, which are now classified as a rather vague category of pre-higher education, there is also a need to make appropriate management decisions and legal and regulatory framework, despite the fact that the Law "On Higher Vocational Education" was adopted in 2019 (06.06.2019 No. 2745-VIII). The adoption of this Law, although it put an end to complete uncertainty with the further development of training of junior specialists in Ukraine, did not solve all the problems, related to the activities of technical schools and colleges. They became the subject of lively discussion of a number of large conferences, held at the initiative of the Ministry of Education and Science, the National Academy of Pedagogical Sciences of Ukraine and regional departments of education.

Currently in Ukraine, for example, there are more than 700 colleges and technical schools with 380,000 students and more than 56,000 teachers. The powerful system annually trains more 
than 100 housand middle-level specialists who have good practical and theoretical knowledge and are equally effective both in practical work and in further undergraduate studies. In addition, experts who assess labor market trends argue that Ukraine, like the world, increasingly needs workers and professionals, rather than people with higher education. For all the conventionality of these assessments, made by scholars in various developed countries, their economies need to maintain such a proportion in the training of specialists, when one master's degree in economics is for two bachelors and seven college graduates. This proportion is confirmed both by the practice of European countries, as evidenced by the data, presented at the meeting of the member states of the Copenhagen process (2008), and the results of this study in the United States [33]. Ukraine's indicators differ significantly from the above values. Today in Ukraine the number of masters and bachelors is almost three times (7.4 and 2.6) more than the number of graduates of colleges and vocational schools.

Given the revival of industrial production in Ukraine, while maintaining the outflow of skilled labor abroad, Ukraine will need a radical change in the situation. We believe that the recent decision of the authorities to exempt those school graduates who do not plan to enter HEI from EIE plays a positive role here. However, it should be borne in mind, that this should not prevent these people from obtaining higher education in the future. Therefore, the Ministry of Education and Science of Ukraine should continue to work on improving the external evaluation, increasingly moving away from its absolutization. Along with this, there are a number of other issues, related to the functioning of vocational and higher education. It is again a question of seeking to implement the principles of dual education at this level and of the possible simplification of the taxation of these educational institutions, in connection with their attempts to provide them with their own earnings by entering the market with their own products and services. Abroad, such incomes usually account for 10 to $15 \%$ of the total income of an educational institution of this type. Domestic tax legislation does not yet allow this to be done in Ukraine, which slows down the development of educational institutions that train people of working professions and specialists at the junior level.

It should be noted, that despite all the difficulties of the reform transformations, the education system in Ukraine is now acquiring new shapes and qualities. On the one hand, the Ukrainian educational system is becoming recognizable for Europe and the world and is already beginning to ensure the international mobility of Ukrainian graduates, and on the other hand, the quality of their training is beginning to better meet the demands of the time and the labor market. In addition, Ukraine continues to be attractive for education by other countries. The latter, of course, applies only to higher education, bachelor's degree, master's degree and training of highly qualified personnel - doctors of philosophy and doctors of science. Therefore, we will analyze the state and problems of higher education reform in Ukraine.

Since higher education is directly "tied" to real production by the industrial development and outpacing growth of agriculture, the slow entry of Ukraine into international industrial relations, the decline of science and other similar processes could not but affect its state and development. Higher education is becoming more mobile, its content and geography are changing, it is adapting more quickly to modern requirements, but it still remains financially low-income, and the teaching staff is aging.

In terms of the issues of this article, the authors analyze the state and development of higher education in Ukraine, except for its content. Explaining this position by the fact that although the latter is a defining feature of any education, it must be provided by internal and external factors, designed to maintain and control the quality of education - drew attention to the basic functional principles of higher education. The existing system of EIE in Ukraine is sufficient to meet the needs of the country and become a significant factor in the international training market. One of the first problematic issues to be addressed in the field of higher education is the issue of staffing students at the expense of the state budget and the contract form of education.

\section{Discussion}

In order to preserve the existing system of higher education in Ukraine, it should be noted the recently adopted form of the so-called indicative tuition fees at HEI, directed at stimulating the departure of Ukrainian students to study abroad and make higher education unattainable for 
large segments of Ukrainian society, as well as put unequal conditions in public and private higher education institutions in Ukraine. The market, with its complex economic, social, political and other dimensions, must determine the level of tuition fees within the country. This payment should not be manipulated. In our opinion, the Ministry of Education and Science and local education authorities should slowly move away from petty care for higher education, leaving only control over their spending of budget funds and quality control of education. The rest of the issues should be unconditionally referred to the decision of HEI itself.

The current legislation of Ukraine determines the amount of state funding for the preparation of bachelors and masters. This circumstance should become the basis for determining the quantitative indicators of those entrants who will be able to study at public expense. The absolute number of such graduates each year will be different, depending on the total number of graduates of the current school year and those who pass the external examination from among the graduates of previous years. All those who, thanks to the results of their training, won the right to study at the expense of the state should receive special certificates and only then pass a competitive selection for specific HEIs. The Ministry of Education and Science should not allocate public procurement places, but only deal with public procurement for those specialties that are not in demand, but are critical for society and business. Exceptions in this regard, in our opinion, should be teachers and medical specialties, training of the military, railway workers, etc., depending on the situation in a particular area. Science in universities should develop at a faster pace and be evaluated by the state not on the basis of imaginary priorities, but on the basis of real scientific achievements of HEIs.

We will pay special attention to the peculiarities of educating and training of teachers, on which the quality of high school directly depends. In our opinion, teaching specialties should be prepared at the expense of the state, at least within a sufficient perspective, until the specialty of a teacher gains sufficient social prestige. Under such conditions, it would be possible for future teachers to raise the requirements for their level of training and work in rural areas, depressed areas, etc. In addition, a separate sectoral teacher training program for national minority schools should be developed and implemented in Ukraine, and there are, as is known, more than 400 and 375 schools in Ukraine where classes for national minorities operate.

In addition, the system of teacher training could include the redistribution of recruitment and training of bachelors and masters, as well as highly qualified personnel. For example, regional pedagogical HEIs could recruit more bachelors, and masters would have to study at leading pedagogical universities. The main volumes of training of highly qualified specialists should be given there as well.

March 23, 2021 Order No. 610 of Ministry of Economy, Trade and Agriculture of Ukraine, after an open procedure for public discussion, approved a very important and significant document in this regard: Professional standard for a group of professions "Teachers of higher education", which in p.p. 1.9. "Conditions of admission to work in the profession" logically specifies that "Teacher positions may be held by persons who have a scientific degree and/or academic title, master's degree or educational qualification level of a specialist in the field of knowledge in accordance with the teaching profile." But, despite the fact that progressive educational reforms are designed to improve the quality of teaching and learning, they may increase the risk of decline ... After all, unfortunately, we must state the fact that now "experts in educational policy", "reformers" are often indeed representatives of organizations that in no way support the ideas of nation-building of Ukrainian educational policy, which have a very "strange" idea of the philosophy of education and pedagogy, psychology and neurophysiology of human, pedagogical skills, its methodology, history and Ukrainian origins. After all, it is pedagogical skill (a set of personality traits that provides self-organization of a high level of professional activity on a reflexive basis) that determines the effectiveness of modern Ukrainian statehood through "sensation", "humanization" of professional actions of the Teacher [34]. Thus, the phenomenon of pedagogical skills, by definition, is the fundamental basis of the theory and practice of educational policy to improve the quality of teaching and learning in the EU countries.

Issues of social justice and the prestige of the work of teachers, college and HEI educators, and scientists in Ukraine remain important. In total, there are more than 0.5 million highly educated people who must constantly work on themselves in order to keep up with progress and give 
proper knowledge to a pupil, student and bring up a worthy change. The need for decent pay for these people has always been well understood by the authorities. Without the full functioning of education and science, the normal development of society and the state is fundamentally impossible. This determines the importance of financial, organizational and intellectual reform of the educational system of Ukraine as the basis of a strong, developed and modern state in the modern world.

Obviously, it is currently not enough to be competent in one area that is directly related to the type of work - the ability to specify priority goals and think critically, negotiate and be creative all this often requires new and balanced habits and approaches to reforming the education system. Only a Master Teacher can easily, freely and fascinatingly explain an educational material, realizing the peculiarities of the impact of transformational processes of information and digital educational space on the modern generation to influence the further development of mankind ... The basis of harmonious quality education, where Master Teachers organize pedagogical interaction, is the development of professional skills of teachers, when the professionalism of a teacher is considered from the standpoint of their training, performance appraisal, personal moral qualities and skill level. What is enshrined in the relevant Standard today. In this context, the issues of concretizing the value content and developing a methodology for training competent professionals in the field of educational policy for Ukraine, on the one hand, and personal and professional selection, training for work in the field of state education policy - on the other, gain special importance. In many EU countries, in addition to short-term refresher courses for educators, there are educational programs in higher education institutions - training modules for specialists in the field of continuing vocational training for adults. The government provides financial support to students. In some cases, students study for free [2]. After all, the main mission of a teacher remains unchanged throughout the existence of mankind - to pass on valuable experience, to prepare the younger generation for a successful future life.

The practical significance of the study of modern processes of reforming the educational policy of Ukraine in terms of comparative analysis with the European Union is to substantiate recommendations for promising areas of progressive experience in reforming educational policy of the EU in Ukraine; to develop a theoretical holistic dynamic conceptual model of educational policy reform for the national education system; preparation of the textbook "Educational Policy of Ukraine" in the future, to introduce guidelines for specialists in the field of educational policy in terms of their psychological and pedagogical training; to develop and to implement the educational and methodological complex "Psychological and pedagogical training of specialists in the field of educational policy on the basis of comparative analysis" in the education system, the program of the special course "Fundamentals of pedagogical skills for specialists in the field of educational policy".

The significance of the work is determined by the possibility of further study of the genesis of synergetic ideas in a given direction. The provisions and conclusions, proposed in the work, contribute to the further development of such a field of knowledge as pedagogical comparative studies, synergetics of pedagogy, philosophy of education. This study can also serve as an impetus to expand the classic parameters of selection and training and retraining of civil servants in education.

\section{Conclusions}

Summarizing the above, we note that the main aspects of ensuring the effectiveness of the implementation of a holistic dynamic model of reforming the educational policy of Ukraine in the context of European integration are the provisions that:

- reforming the educational policy of Ukraine will be more effective if it is based on the human-centered orientation of the educational process; the principles of democracy, integrity and nation-building, ethical, aesthetic and culturally appropriate development of an individual, which characterize the theory and practice of educational policy in the European Union;

- the concept of a holistic dynamic model of reforming the educational policy of Ukraine will be effective if its legislative instrument is concretized by a comprehensive standardization of the content of the education system based on the experience of the European Union;

- Theory and methods of development and implementation of the Target program of professional and pedagogical selection and training of specialists in the field of educational policy for Ukraine will provide consistent and systematic vocational training, which focuses on the personality of educators 
and experts in education, updating their needs for professional self-knowledge and self-education, development of a moral and humanistic professional patriotic position for the organization of a productive dialogue in order to forecast, design and implement educational policy in Ukraine;

- the practice of implementing a holistic dynamic model of educational policy in Ukraine will be effective if the work is carried out to take into account the relevant prerequisites (conditions-resources) for the implementation of the Target program of professional and pedagogical selection and training of specialists in education policy for Ukraine:

- modernization of the educational process in the context of globalization and digitalization of the information environment;

- development of Soft Skills specialists in the field of educational policy in the context of European integration of education;

- knowledge by specialists in the field of educational policy of one's own personality as a kind of tool for reflective management of the behavior and activities of others,

- awareness and personal acceptance of the values and characteristics of activities in the field of educational policy;

- mastering the psychological and pedagogical techniques of interaction management in the organization of the educational process of adults;

- awareness of the role of motives for self-actualization of an individual as a determinant of his/her professional activity; highlighting the dominant role of moral and humanistic orientation in the system of professional values of specialists in the field of educational policy for Ukraine.

\section{References}

[1] Dzhurylo, A. P., Hlushko, O. Z., Lokshyna, O. I. et. al. (2018). Transformatsiini protsesy u shkilnii osviti krain Yevropeiskoho Soiuzu ta SShA. Kyiv: TOV «KONVI PRINT», 192.

[2] Bondarenko, V., Semenova, A. (2020). Targets of strategic development of educational policy of Ukraine under integration into the european educational area: social and personal dimensions of cultural and historical integrity. Education: Modern Discourses, 3, 13-26. doi: http://doi.org/10.37472/2617-3107-2020-3-02

[3] Kremen, V. H. (Ed.) (2008). Entsyklopediia osvity. Kyiv: Yurinkom Inter, 1040.

[4] Shulha, N. D. (2011). Sutnisni kharakterystyky poniattia «derzhavna osvitnia polityka». Derzhavne upravlinnia: teoriia i praktyka, 2. Available at: http://academy.gov.ua/ej/ej14/txts/Shulga.pdf

[5] von der Leyen, U. (2019). Political guidelines of the Commission 2019-2024. Available at: https://ec.europa.eu/info/sites/info/ files/political-guidelines-next-commission_en_0.pdf

[6] Rome Ministerial Communiqué (2020). Available at: http://www.ehea.info/Upload/Rome_Ministerial_Communique.pdf

[7] Developing Key Competences at School in Europe: Challenges and Opportunities for Policy (2012). Eurydice Report. European Commission/EACEA/Eurydice. Luxembourg: Publications Office of the European Union, 68.

[8] Berezivska, L. (2011) Reformuvannia shkilnoi osvity Ukrainy v umovakh derzhavotvorennia (pochatok 90-kh rokiv KhKh st.). Molod i rynok, 6 (77), 17-21.

[9] Protasova, N. H., Luhovyi, V. I. (2012). Reformuvannia osvity v Ukraini: derzhavno-upravlinskyi aspekt. Kyiv; Lviv: NADU, 456.

[10] Avsheniuk, N. M., Diachenko, L. M., Kotun, K. V., Marusynets, M. M., Ohiienko, O. I., Sulyma, O. V., Postryhach, N. O. (2017). Zarubizhnyi dosvid profesiinoi pidhotovky pedahohiv. Kyiv: DKS «Tsentr», 83.

[11] Radaelli, C. M. (2000). Whither Europeanization? Concept stretching and substantive change. European Integration online Papers, 4 (8). doi: http://doi.org/10.2139/ssrn.302761

[12] Schriewer, J., Orivel, F., Swing, E. S.; Schriewer, J. (Ed.) (2000). European Educational Systems: the Framework of Tradition, Systemic Expansion and Challenges for Restructing. Problems and Prospects of European Education. Westport: Greenwood Publishing Group, Incorporated, 1-20.

[13] Dzvinchuk, D. I. (2007). Suchasni tendentsii rozvytku ta upravlinnia osvitoiu. Kyiv, 36.

[14] Wößmann, L., Schütz, G. (2006). Efficiency and Equity in European Education and Training Systems. Munich: EENEE, 42.

[15] Krystopchuk, T. Ye. (2016). Osoblyvosti detsentralizatsii upravlinnia osvitoiu: dosvid yevropeiskykh krain. Psykholohopedahohichni osnovy humanizatsii navchalno-vykhovnoho protsesu v shkoli ta VNZ, 2, 108-117. Available at: http://nbuv. gov.ua/UJRN/Ppog_2016_2_17

[16] Grek, S., Lawn, M. (2012). Europeanizing Education: governing a new policy space. Oxford: Symposium Books Ltd., 172. 
[17] Urbanovič, J., Patapas, A. (2012). 'Decentralisation Reforms of Education Management: Theoretical and Practical Issues' Viešoji Politika ir Administravimas. Public Policy and Administration, 11 (4), 659-671.

[18] Radó, P. (2010). Governing Decentralized Education Systems. Systemic Change in South Eastern Europe. Budapest: Local Government and Public Service Reform Initiative, Open Society Foundations, 138-156.

[19] La Rosa, M. (2014). EU: Education policies and third countries. Civilian power or just foreign policy? MA in European Studies. Lund University, 79.

[20] Bernbaum, M. (2011). Equip 2 Lessons Learned in Education. Decentralization. Washington: USAID, EQUIP 2 and FHI, 360.

[21] Developing Key Competences at School in Europe: Challenges and Opportunities for Policy. Eurydice Report. European Commission/EACEA/Eurydice (2012). Luxembourg: Publications Office of the European Union, 68.

[22] Hudson, C. (2007). Governing the Governance of Education: The State Strikes Back? European Educational Research Journal, 6 (3), 266-282. doi: http://doi.org/10.2304/eerj.2007.6.3.266

[23] Ladrech, R. (2001). Europeanization and Political Parties: Towards a Framework for Analysis. Keele European Parties Ree search Unit (KEPRU) Working Paper 7, Available at: https://www.keele.ac.uk/media/keeleuniversity/group/kepru/KEPRU\%20 WP\%207.pdf Last accessed: 17.11.2018

[24] Robert, B. (2010). The Europeanization of Education Policies: A Research Agenda. European Educational Research Journal, 9 (4), 519-524. doi: http://doi.org/10.2304/eerj.2010.9.4.519

[25] Western Europe - Educational Roots, Reform in the Twentieth Century, Contemporary Reform Trends, Future Challenges. The Education Encyclopedia. Available at: http://education.stateuniversity.com/pages/2547/

[26] Savchenko, O. (2018). Stages of modernisation of the content of primary school education: Ukrainian experience. Education: Modern Discourses, 1, 130-141. doi: http://doi.org/10.32405/2617-3107-2018-1-12

[27] Stratehiia reformuvannia osvity v Ukraini: Rekomendatsii z osvitnoi polityky (2003). Kyiv: “K.I.S.”, 296. Available at: https:// www.irf.ua/files/ukr/programs_edu_ep_409_ua_ref_strategy.pdf

[28] Putcha, V., Noiman, M., Zaplotynska, O., Sofii, N. (2018). «Pidtrymka pratsivnykiv doshkilnoi osvity na derzhavnomu rivni: doshkilna osvita v Ukraini». Vashynhton: Rezultaty dlia rozvytku, 6-7. Available at: https://www.r4d.org/wp-content/ uploads/ECWI-Ukraine-Full-Report_Ukr.pdf

[29] Kremenia, V. H. (Ed.) (2016). Natsionalna dopovid pro stan i perspektyvy rozvytku osvity v Ukraini. Kyiv: Pedahohichna dumka, 448.

[30] Oryshchuk, F., Nadelniuk, O. (2020). Natsyia bezrabotnikh bakalavrov. Shest problem obrazovanyia v Ukrayne. LIGA.net. Available at: https://www.liga.net/society/articles/natsiya-bezrabotnyh-bakalavrov-shest-problem-obrazovaniya-v-ukraine

[31] Education and Training MONITOR 2019 (2019). Luxembourg: Publications Office of the European Union.

[32] Vysotska, T. M. (2020) Autocephaly of the Orthodox as a factor of change in the religious, ecclesiastical and socio-political life of Ukraine. Kyiv, 334.

[33] Bezzub, I. Zakon «Pro fakhovu peredvyshchu osvitu»: zmist ta ochikuvannia. Hromadska dumka pro pravotvorennia, 13-14 (178-179), 11-19.

[34] Semenova, A. (2016). Tsinnisnyi vymir dosvidu subiektiv pedahohichnoi dii. Odesa: Bondarenko, 436. Available at: http:// www.pedagogic-master.com.ua/public/semenova/tsinisnyi_vymir.pdf

Received date 03.08.2021

(C) The Author(s) 2021

Accepted date 23.11.2021

Published date 30.11.2021

This is an open access article under the Creative Commons CC BY license

How to cite: Bondarenko, V., Semenova, A., Vysotska, T. (2021). Processes of reforming the educational policy of Ukraine and the countries of the European Union: a comparative analysis. EUREKA: Social and Humanities, 6, 52-67. doi: http:// doi.org/10.21303/2504-5571.2021.002195 